Egyptian Journal of Aquatic Biology \& Fisheries

Zoology Department, Faculty of Science,

Ain Shams University, Cairo, Egypt.

ISSN $1110-6131$

Vol. 26(1): 63 - 81 (2022)

www.ejabf.journals.ekb.eg

\title{
Heavy metals concentration patterns in the Atlantic horse meckrel (Trachurus trachurus), the Round sardinella (Sardinella aurita) and the Common panadora (Pagellus erythrinus) from northwestern Egyptian coasts
}

\author{
Rabia A. El Zlitne ${ }^{1,7}$, Mahmoud S. Sharaf ${ }^{2}$, Alaa Eldin Eissa ${ }^{2}$, Awad Abdelbaky ${ }^{2}$, Heba M. Salem ${ }^{3}$, \\ Abeer E. Mahmoud ${ }^{4}$, Fayza, A. Sdeek ${ }^{5}$, Mona M. Ismail ${ }^{6}$, Eman M. Ismail ${ }^{7}$, Manal M. Zaki ${ }^{7}$ \\ ${ }^{1,7}$ Department of Preventive Medicine, Faculty of Veterinary Medicine, University of Tripoli, Libya \\ ${ }^{2}$ Department of Aquatic Animal Medicine and Management, Faculty of Veterinary Medicine, Cairo \\ University, Giza 12211 Egypt \\ ${ }^{3}$ Department of Poultry diseases, Faculty of Veterinary Medicine, Cairo University, Giza 12211 Egypt \\ ${ }^{4}$ Department of Fish Diseases, Animal Health Research Institute, Assiut Provincial Laboratory, Agriculture \\ Research Center, Dokki, Egypt \\ ${ }^{5}$ Pesticide Residues Environmental Department، Central Agricultural Pesticide Centre, Agriculture \\ Research Center, Dokki, Egypt \\ ${ }^{6}$ Department of Fish Diseases and Management, Faculty of Veterinary Medicine, Suez Canal University, \\ Ismailia Egypt \\ ${ }^{7}$ Department of Veterinary Hygiene and Management, Faculty of Veterinary Medicine, Cairo University, \\ Giza 12211 Egypt \\ "Corresponding Author: aeissa2005@gmail.com; aeissa2012@cu.edu.eg
}

ARTICLE INFO

Article History:

Received: Dec. 22, 2021

Accepted: Jan. 8, 2022

Online: Jan. 17, 2022

\section{Keywords:}

Atlantic horse mackerel;

Common panadora;

Round sardinella,

Heavy metals;

Southwestern

Mediterranean coasts,

Egypt.
ABSTRACT

Heavy metals are considered among the most serious contaminants of aquatic ecosystems, due to their biomagnifications in the tissues of fish and humans. Thus, the current study was planned to shed the light on the importance of heavy metal biomonitoring on a regular basis to ensure high quality, healthy fish, and fish products for consumers. Laboratory assessment has indicated that the highest bioaccumulation pattern of Zinc $(\mathrm{Zn})$, Copper $(\mathrm{Cu})$, Cadmium $(\mathrm{Cd})$, Lead $(\mathrm{Pb})$ and Mercury $(\mathrm{Hg})$ was recorded in Atlantic horse mackerel followed by Round Sardinella then Common panadora. Statistical analysis revealed the presence of relative variation in the accumulation patterns of heavy metals between different examined organs. The liver, spleen, and kidney have alternatively adopted the highest accumulation organ for $\mathrm{Zn}, \mathrm{Cu}, \mathrm{Cd}, \mathrm{Pb}$, and $\mathrm{Hg}$, while gills were the least organ. The recorded histopathological alterations within liver, kidney, spleen, gills, and muscles have confirmed that Atlantic horse mackerel were the most affected fish species followed by Round sardinella then Common panadora. The study concluded that fish from the northwestern coast of Egypt are relatively healthier than fish from other coasts on the Mediterranean either from the European or Arabian side due to lower heavy metal levels in their flesh, and Atlantic horse mackerel could promote it as a biomonitor for heavy metal pollution.

\section{INTRODUCTION}

Heavy metals are considered one of the most serious contaminants of aquatic ecosystems, that have high potential to enter and accumulate in food chain (Tam and 
Wong, 2000; Erdoğrul and Erbilir, 2007; Yousif et al., 2021). Normally heavy metals are present in water in low concentrations, but extensive anthropogenic activities lead to increase levels of metals in water to become toxic concentrations that are capable to accumulate causing damage to ecological system under certain environmental conditions. (Jefferies and Firestone, 1984; Freedman, 1989; Ismail et al., 2021; Mahjoub et al., 2021).

Anthropogenic activities include domestic and municipal wastes run off, sewage irrigation, mining discharges, discharges from agricultural areas using pesticides, smelting, combustion of fossil fuel refining, and former industrial sites, are the main sources of heavy metal pollution in aquatic environments. (Singh and Steinnes, 1994; Kumar Singh et al., 2007; Rakib et al., 2021).

Those activities directly contribute to spread and accumulation of contaminants in the bottom of coastal ecosystems which act as pollutants depository. Sediment contaminants could be released to the overlying and surface water, resulting in potential adverse effects to aquatic organisms (Daskalakis and O'Connor, 1995; Long et al., 1995; Argese et al., 1997).

Coastal ecosystems are characterized by high organic matter and nutrients deposition from the mainland, they have fragile nature that primarily depend on earthy conditions (Yáñez-Aracibia and Sánchez-Gil, 1988). Industrialization in coastal countries that are well known by exploitation, exportation and importation economics causing serious damage to coastal ecosystems, especially by metals contamination (Cardoso et al., 2001). These contaminants have mutagenic and toxigenic effect on kidneys, nervous, reproductive, and endocrine systems (Nirmala et al., 1999; Ketata et al., 2007; Liu et al., 2008; Brar et al., 2009). Moreover, trace metals have the ability to bioaccumulate and biomagnified in edible aquatic organisms, thus, representing a health hazard risk to top fish predators, including humans (Huang et al., 2006; Díez et al.,2009).

From the public health point of view, the consumption of fish containing high levels of metals is of a great concern because chronic exposure to heavy metals can cause critical health problems. Chronic cadmium exposure has been associated with renal failure, bone fragility and as a cancer-causing agent in humans. Also, zinc is an essential nutrient for proper growth, low levels of zinc can cause problems, but high levels of zinc have harmful effects on human health (Agency for Toxic Substances and Disease Registry, 2004). Mercury ( $\mathrm{Hg}$ ) is one of the pollutants that have hazardous effects on both aquatic animals and humans. Methyl mercury formed through the bacterial methylation of inorganic mercury in aquatic sediments; is the most toxic chemical compound of mercury. In fact, almost the entire amounts of mercury found in fish muscles as methyl mercury, which affects adversely on the kidneys and the central nervous system, particularly during developmental stages, as it crosses both the placenta 
and the blood-brain barrier (Staessen et al., 1999; Hellstrom et al., 2001; Clarkson, 2002; Honda et al., 2003).

Ultimately, feeding on fish containing methyl mercury and other heavy metals for longer periods will deleteriously affects the human health by suppressing their immune system, increase liability to bacterial / viral invasion, increase frequency of cancer development, increase frequency of renal / hepatic failure and development of critical cases of endocrine disruption. Therefore, the current study aimed to evaluate the levels of five heavy metals in the muscles and organs of three importantly economic commercial marine fish (Atlantic horse mackerel, Round sardinella and Common panadora) that are frequently consumed by Egyptian consumers.

\section{MATERIALS AND METHODS}

\section{Sampling area}

Water and fish samples were collected from the northwestern Egyptian coasts of the Mediterranean (Marsa Matrouh \& Saloum Bay).

\section{Water samples}

Water samples were collected using fishermen boats between 10:00 and 12:00 a.m. at a depth of $30 \mathrm{~cm}$ and stored at $4^{\circ} \mathrm{C}$ in sterile glass bottles, acidified with concentrated hydrochloric acid $(\mathrm{HCl})$ for preservation. The reason for choosing the northwestern Egyptian coasts of the Mediterranean is scarcity of Latures about heavy metal concentration in wild fisheries at this pristine area of the Egyptian state with wild caught marine fish as the main fish utilized by the native people.

\section{Fish samples}

A total of 50 fish sample of each of the following fish species were caught alive or sometimes freshly dead during the period of August 2020 - August 2021. The sampled live fish species were, Common pandora (Pagellus erythrinus), while the sampled freshly dead species were Atlantic horse - mackerel (Trachurus trachurus) and Round sardinella (Sardinella aurita). The fish total length was measured using a caliber and weights were measured using digital scale. Live fish were stored in well aerated Styrofoam boxes containing sea water while freshly dead fish were stored on ice in icebox till transferred to the Aquatic Animal Medicine \& Management (AAMM) laboratory of the Faculty of Veterinary Medicine, Cairo University.

\section{Samples processing}

Fish were dissected from left side using three-line incision (Eissa, 2016) to obtain liver, kidney, spleen, gills, and muscles (Fig. 2). Each tissue sample was divided into two parts. The first part was kept frozen at $-20^{\circ} \mathrm{C}$ for investigating heavy metals concentrations and the second one was fixed in $10 \%$ buffered neutral formalin for histopathological examination. 


\section{Heavy metals assessment}

Trace elements were measured in water and tissue samples according to APHA, (2005), using flame atomic absorption spectrophotometer (Thermo Scientific, UK) with double beam and deuterium background corrector. Tissue samples were dried, aciddigested, and diluted with de-ionized water to known volume using the dry-ashing procedure proposed by Hseu, (2004). Analytical blanks were run in the same way as the samples, and concentrations were determined using standard solutions prepared in the same acid matrix. All reagents used were of analytical grade (Merck, USA). Standards for instrument calibration were prepared based on mono-element certified reference solution inductively coupled plasma standard (Merck). Standard reference material (National Institute of Standards and Technology [NIST], USA) was used to validate analysis, and the metal recoveries ranged between 90 and $110 \%$. Concentrations of all heavy metals in water are expressed as $\mathrm{mg} / \mathrm{l}(\mathrm{ppm})$ and $\mu \mathrm{g} / \mathrm{gm}$ wet weight in tissues.

\section{Histopathological examination}

The fixed fish tissues (gills, kidney, liver, spleen) were preserved in $10 \%$ buffered formalin, embedded within paraffin, sectioned at $5 \mu \mathrm{m}$, and stained with Hematoxylin and Eosin (H\&E) according to the method described by Prophet et al. (1992). The histopathological alterations of $\mathrm{H} \& \mathrm{E}$-stained tissue sections were microscopically assessed under low / high microscopic powers.

\section{Statistical analysis}

The data obtained was statistically assessed by the analysis of variance (ANOVA) through General Linear Model procedure of SPSS (14.0) software. The values were expressed as means \pm standard error. LSD multiple range tests were used to test the significance of difference between means by considering the differences significant at $\mathrm{p}<$ 0.05. In all cases, $\mathrm{P}<0.05$ was the accepted significance level. Correlation coefficient (r) also used (SPSS, 20).

\section{RESULTS}

\subsection{Morphometric measures}

The range of lengths of the sampled Atlantic horse mackerel (T. trachurus) was $13.5 \mathrm{~cm}-32 \mathrm{~cm}$ while mean was $23.25 \pm 8.43 \mathrm{~cm}$. The body weight range was $24.8-417.5$ gm while mean was $210 \pm 183.59$ gm (Table 1). The range of lengths of the sampled Round sardinella ( $S$. aurita) was $18.0-21.5 \mathrm{~cm}$ while mean was $19.75 \pm 1.28 \mathrm{~cm}$. The body weight range was 67.0-120.5 gm while mean was 93.08 $\pm 18.14 \mathrm{gm}$ (Table 1). The range of lengths of the sampled Common panadora (P. erythrinus) was $14.5-18.0 \mathrm{~cm}$ while mean was $16.36 \pm 1.38 \mathrm{~cm}$. The body weight range was $69.7-164.1 \mathrm{gm}$ while mean was $98.10 \pm 33.33 \mathrm{gm}$ (Table 1). It was noticeable that lengths pattern was $T$. trachurus $>S$. aurita $>$ P. erythrinus while weights pattern was T. trachurus $>$ P. erythrinus $>S$. aurita (Table 1) 
Table 1. The range and mean of lengths and weights of the examined fishes.

\begin{tabular}{ccrcrc}
\hline \multirow{2}{*}{ Fish species } & \multirow{2}{*}{$\begin{array}{c}\text { No. of } \\
\text { Fish }\end{array}$} & \multicolumn{2}{c}{ Total length in Cm } & \multicolumn{2}{c}{ Total weight in gm } \\
\cline { 3 - 6 } & & Range & Mean \pm SD & Range & Mean \pm SD \\
\hline Trachurus trachurus & 50 & $13.5-32.0$ & $23.25 \pm 8.43$ & $24.8-417.5$ & $210 \pm 183.59$ \\
\hline Sardinella aurita & 50 & $18.0-21.5$ & $19.75 \pm 1.28$ & $67.0-120.5$ & $93.08 \pm 18.14$ \\
\hline Pagellus erythrinus & 50 & $14.5-18.0$ & $16.36 \pm 1.38$ & $69.7-164.1$ & $98.10 \pm 33.33$ \\
\hline
\end{tabular}

\subsection{Heavy metal concentration in seawater}

The mean concentration of the selected heavy metals in seawater from the Egyptian northwestern coasts (Salloum Bay \& Marsa Matrouh) was 0.2280 \pm 0.0060 , $1.0466 \pm 0.0010,0.028 \pm 0.0006,0.038 \pm 0.0002$ and $0.029 \pm 0.0001 \mathrm{mg} / \mathrm{L}$ for $\mathrm{Zn}, \mathrm{Cu}, \mathrm{Cd}$, $\mathrm{Pb}$ and $\mathrm{Hg}$ respectively (Table 2; Figure 1).

Table 2. Heavy metals concentration in water (concentration in $\mathrm{mg} / \mathrm{L}$ of sea water) of sampled from the northeastern coast of Egypt.

\begin{tabular}{cccc}
\hline $\begin{array}{c}\text { Heavy } \\
\text { metals }\end{array}$ & $\begin{array}{c}\text { Concentration in water in } \\
\mathbf{m g} / \mathbf{L}\end{array}$ & $\begin{array}{c}\text { Permissible limit WHO } \\
\mathbf{( 1 9 9 3 )}\end{array}$ & $\begin{array}{c}\text { Permissible limit US- } \\
\text { EPA (2001) }\end{array}$ \\
\hline $\mathbf{Z n}$ & $0.2280 \pm 0.0060$ & 5 & 5 \\
\hline $\mathbf{C u}$ & $1.0466 \pm 0.0010$ & 1 & 1 \\
\hline $\mathbf{C d}$ & $0.028 \pm 0.0006$ & 0.005 & 0.01 \\
\hline $\mathbf{P b}$ & $0.038 \pm 0.0002$ & 0.050 & 0.050 \\
\hline $\mathbf{H g}$ & $0.029 \pm 0.0001$ & 0.050 & 0.050 \\
\hline
\end{tabular}

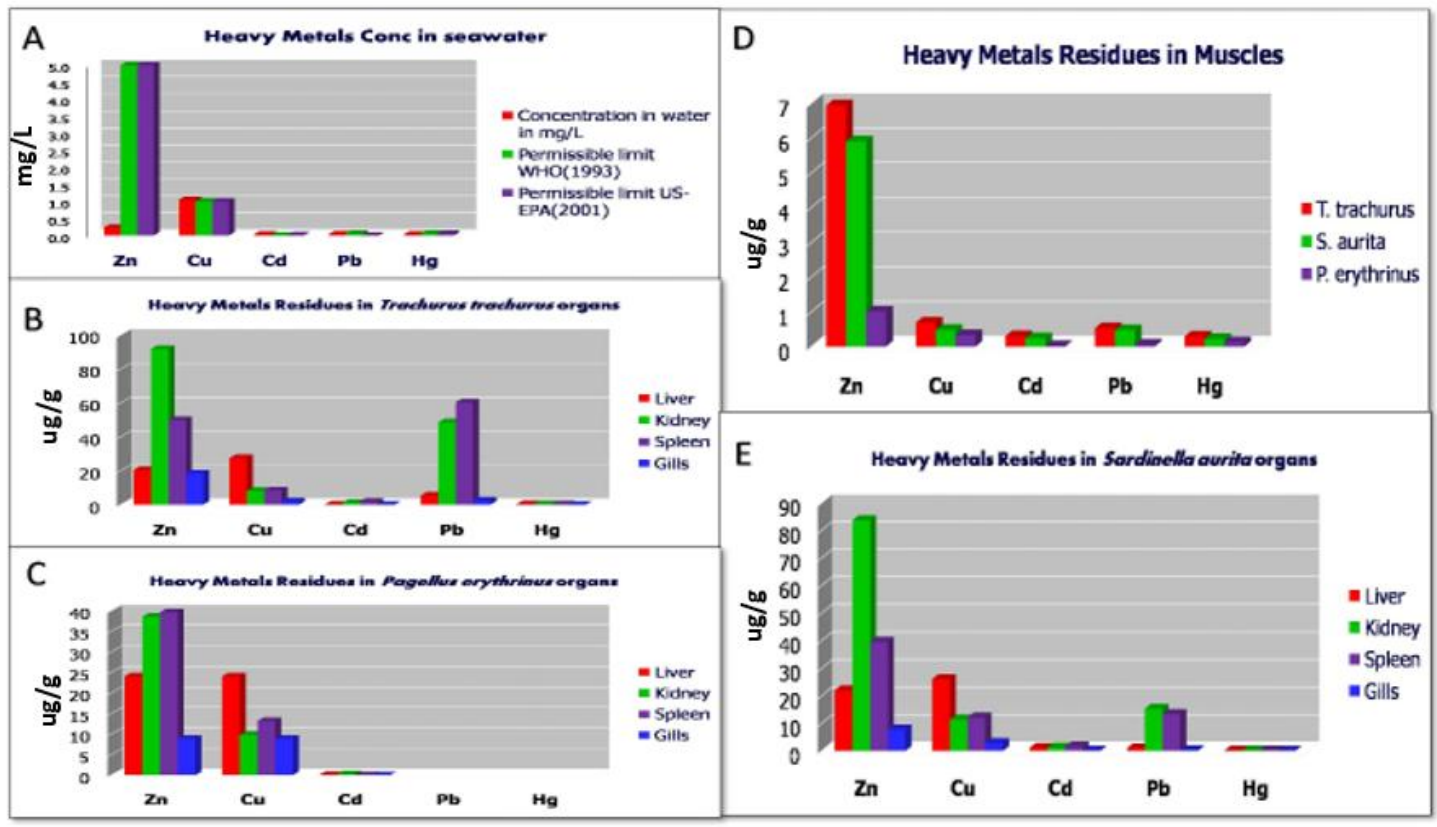

Fig. 1. A: Heavy metals concentration in seawater samples from the Mediterranean Egyptian northwestern coasts (Salloum Bay \& Marsa Matrouh). B: Heavy metals concentration in muscles of the three examined marine fish from Mediterranean Egyptian northwestern coasts. C: Heavy metals concentration in organs of the Pagellus erythrinus organs from Mediterranean Egyptian northwestern coasts. D: Heavy metals concentration in muscles of the three examined marine fish from Mediterranean Egyptian northwestern coasts. E: Heavy metals concentration in organs of the Sardinella aurita from Mediterranean Egyptian northwestern coasts. 


\subsection{Heavy metal concentration in muscle tissues}

Results indicated that the $\mathrm{Zn}$ concentration in the examined muscle samples of the three marine fish collected from the Egyptian northwestern coasts (Salloum Bay \& Marsa Matrouh) were $6.94 \pm 0.33,5.9 \pm 0.25,1.01 \pm 0.24 \mathrm{ug} / \mathrm{gm}$ for $T$. trachurus, $S$. aurita and $P$. erythrinus respectively. The $\mathrm{Cu}$ concentration was $0.69 \pm 0.09,0.48 \pm 0.07$ and $0.33 \pm 0.05$ ug/ gm for T. trachurus, $S$. aurita and P. erythrinus respectively. The Cd concentration was $0.30 \pm 0.03,0.24 \pm 0.01$ and $0.02 \pm 0.006 \mathrm{ug} / \mathrm{gm}$ for $T$. trachurus, S. aurita and $P$. erythrinus respectively. The $\mathrm{Pb}$ concentration was $0.53 \pm 0.26,0.47 \pm 0.17$ and $0.06 \pm 0.05$ ug/ gm for $T$. trachurus, $S$. aurita and $P$. erythrinus respectively. Finally, $\mathrm{Hg}$ concentration was $0.29 \pm 0.03,0.22 \pm 0.01$ and $0.13 \pm 0.02 \mathrm{ug} / \mathrm{gm}$ for T. trachurus, S. aurita and P. erythrinus respectively (Table 3; Fig. 1).

Table 3. Heavy metals concentration in muscles (concentration in $\mu \mathrm{g} / \mathrm{gm}$ tissue $\pm \mathrm{SE}$ ) of the three marine fishes sampled from the northeastern coast of Egypt.

\begin{tabular}{cccc}
\hline $\begin{array}{c}\text { Heavy } \\
\text { metals }\end{array}$ & Trachurus trachurus & Sardinella aurita & Pagellus erythrinus \\
\hline $\mathbf{Z n}$ & $6.94 \pm 0.33$ & $5.9 \pm 0.25$ & $1.01 \pm 0.24$ \\
\hline $\mathbf{C u}$ & $0.69 \pm 0.09$ & $0.48 \pm 0.07$ & $0.33 \pm 0.05$ \\
\hline $\mathbf{C d}$ & $0.30 \pm 0.03$ & $0.24 \pm 0.01$ & $0.02 \pm 0.006$ \\
\hline $\mathbf{P b}$ & $0.53 \pm 0.26$ & $0.47 \pm 0.17$ & $0.06 \pm 0.05$ \\
\hline $\mathbf{H g}$ & $0.29 \pm 0.03$ & $0.22 \pm 0.01$ & $0.13 \pm 0.02$ \\
\hline
\end{tabular}

\subsection{Heavy metal concentration in organs of T. trachurus}

Results indicated that $\mathrm{Zn}$ was accumulated in liver, kidney, spleen, and gills of $T$. trachurus in concentrations of $20.48 \pm 1.91,91.79 \pm 2.03,49.85 \pm 9.7$ and $18.51 \pm .33 \mu \mathrm{g} / \mathrm{g}$ dry weight respectively. The $\mathrm{Cu}$ was accumulated in liver, kidney, spleen and gills of $T$. trachurus in concentrations of $27.43 \pm 8.66,8.16 \pm 2.12,8.42 \pm 1.86$ and $1.91 \pm 0.21 \mu \mathrm{g} / \mathrm{g}$ dry weight successively. The $\mathrm{Cd}$ was accumulated in liver, kidney, spleen, and gills of $T$. trachurus in concentrations of $0.16 \pm 0.06,1.23 \pm 0.42,1.83 \pm 0.85$ and $0.09 \pm 0.06 \mu \mathrm{g} / \mathrm{g}$ dry weight, respectively. The $\mathrm{Pb}$ was accumulated in liver, kidney, spleen, and gills of $T$. trachurus in concentrations of $5.48 \pm 1.00,48.52 \pm 9.99,60.29 \pm 12.60$ and $2.56 \pm 0.10 \mu \mathrm{g} / \mathrm{g}$ dry weight respectively. Further, The $\mathrm{Hg}$ was accumulated in liver, kidney, spleen, and gills of $T$. trachurus in concentrations of $0.312 \pm 0.133,0.277 \pm 0.104,0.275 \pm 0.165$ and $0.115 \pm 0.040 \mu \mathrm{g} / \mathrm{g}$ dry weight respectively (Table 4) and (Fig. 1). 
Table 4. Average accumulation of trace heavy metals in liver, kidney, spleen, gills $(\mu \mathrm{g} / \mathrm{g}$ dry weight) in three marine fishes sampled from the northeastern coast of Egypt.

\begin{tabular}{ccccc}
\hline Heavy metal & Organ & Pagellus erythrinus & Trachurus trachurus & Sardinella aurita \\
\hline Zn & Liver & $24.03 \pm 2.67$ & $20.48 \pm 1.91$ & $22.00 \pm 2.00$ \\
\hline & Kidney & $38.56 \pm 3.52$ & $91.79 \pm 2.03$ & $83.69 \pm 1.03$ \\
\hline & Spleen & $39.62 \pm 8.86$ & $49.85 \pm 9.7$ & $39.62 \pm 6.80$ \\
\hline Pattern & Gills & $8.86 \pm 1.9$ & $18.51 \pm .33$ & $7.81 \pm 1.5$ \\
\hline Cu & Liver & $\mathrm{K}>\mathrm{S}>\mathrm{L}>\mathrm{G}$ & $\mathrm{S}>\mathrm{K}>\mathrm{L}>\mathrm{G}$ & $\mathrm{K}>\mathrm{S}>\mathrm{L}>\mathrm{G}$ \\
\hline & Kidney & $9.03 \pm 2.67$ & $27.43 \pm 8.66$ & $26.03 \pm 2.33$ \\
\hline & Spleen & $13.17 \pm 3.43$ & $8.16 \pm 2.12$ & $11.39 \pm 2.00$ \\
\hline Pattern & Gills & $8.86 \pm 1.99$ & $8.42 \pm 1.86$ & $12.17 \pm 3.01$ \\
\hline Cd & Liver & $\mathrm{K}>\mathrm{S}>\mathrm{L}>\mathrm{G}$ & $1.91 \pm 0.21$ & $2.86 \pm 1.99$ \\
\hline & Kidney & $0.07 \pm 0.04$ & $\mathrm{~L}>\mathrm{S}>\mathrm{K}>\mathrm{G}$ & $\mathrm{K}>\mathrm{S}>\mathrm{L}>\mathrm{G}$ \\
\hline & Spleen & $0.27 \pm 0.16$ & $0.16 \pm 0.06$ & $1.07 \pm 0.04$ \\
\hline Pattern & Gills & $0.02 \pm 0.006$ & $1.23 \pm 0.42$ & $1.27 \pm 0.13$ \\
\hline Pb & Liver & $\mathrm{K}>\mathrm{L}>\mathrm{S}>\mathrm{G}$ & $1.83 \pm 0.85$ & $1.65 \pm .02$ \\
\hline & Kidney & $1.00 \pm 0.12$ & $0.09 \pm 0.06$ & $0.08 \pm 0.004$ \\
\hline & Spleen & $15.30 \pm 1.70$ & $\mathrm{~S}>\mathrm{K}>\mathrm{L}>\mathrm{G}$ & $\mathrm{K}>\mathrm{L}>\mathrm{S}>\mathrm{G}$ \\
\hline Pattern & Gills & $0.300 \pm 0.20$ & $5.48 \pm 1.00$ & $3.98 \pm 0.10$ \\
\hline Hg & Liver & $\mathrm{K}>\mathrm{L}>\mathrm{S}>\mathrm{G}$ & $48.52 \pm 9.99$ & $30.52 \pm 6.33$ \\
\hline & Kidney & $0.134 \pm 0.030$ & $60.29 \pm 12.60$ & $28.33 \pm 10.24$ \\
\hline Pattern & Gills & $0.111 \pm 0.024$ & $2.56 \pm 0.10$ & $1.50 \pm 0.45$ \\
\hline & & $\mathrm{S}>\mathrm{K}>\mathrm{L}>\mathrm{G}$ & $\mathrm{K}>\mathrm{L}>\mathrm{S}>\mathrm{G}$ \\
\hline & & $\mathrm{S}>\mathrm{K}>\mathrm{G}>\mathrm{L}$ & $0.312 \pm 0.133$ & $0.130 \pm 0.016$ \\
\hline & & $0.277 \pm 0.104$ & $0.160 \pm 0.051$ \\
\hline & & $0.275 \pm 0.165$ & $0.158 \pm 0.049$ \\
\hline & & $0.115 \pm 0.040$ & $0.060 \pm 0.024$ \\
\hline & & $\mathrm{S}>\mathrm{K}>\mathrm{G}>\mathrm{L}$ & $\mathrm{S}>\mathrm{K}>\mathrm{G}>\mathrm{L}$ \\
\hline & & &
\end{tabular}

\section{5. Heavy metal concentration in organs of S. aurita}

Results indicated that $\mathrm{Zn}$ was accumulated in liver, kidney, spleen, and gills of $S$. aurita in concentrations of $22.00 \pm 2.00,83.69 \pm 1.03,39.62 \pm 6.80$ and $7.81 \pm 1.5 \mu \mathrm{g} / \mathrm{g}$ dry weight successively. The $\mathrm{Cu}$ was accumulated in liver, kidney, spleen, and gills of $S$. aurita in concentrations of $26.03 \pm 2.33,11.39 \pm 2.00,12.17 \pm 3.01$ and $2.86 \pm 1.99 \mu \mathrm{g} / \mathrm{g}$ dry weight successively. The $\mathrm{Cd}$ was accumulated in liver, kidney, spleen, and gills of $S$. aurita in concentrations of $1.07 \pm 0.04,1.27 \pm 0.13,1.65 \pm .02$ and $0.08 \pm 0.004 \mu \mathrm{g} / \mathrm{g}$ dry weight successively. The $\mathrm{Pb}$ was accumulated in liver, kidney, spleen, and gills of $S$. aurita in concentrations of $3.98 \pm 0.10,30.52 \pm 6.33,28.33 \pm 10.24$ and $1.50 \pm 0.45 \mu \mathrm{g} / \mathrm{g}$ dry weight successively. Ultimately, The $\mathrm{Hg}$ was accumulated in liver, kidney, spleen, and gills of $S$. aurita in concentrations of $0.130 \pm 0.016,0.160 \pm 0.051,0.158 \pm 0.049$ and $0.060 \pm 0.024 \mu \mathrm{g} / \mathrm{g}$ dry weight successively (Table 4) and (Fig.1).

\section{6. Heavy metal concentration in organs of P. erythrinus}

Results indicated that $\mathrm{Zn}$ was accumulated in liver, kidney, spleen, and gills of $S$. aurita in concentrations of $24.03 \pm 2.67,38.56 \pm 3.52,39.62 \pm 8.86$ and $8.86 \pm 1.9 \mu \mathrm{g} / \mathrm{g}$ dry weight successively. The $\mathrm{Cu}$ was accumulated in liver, kidney, spleen, and gills of $S$. 
aurita in concentrations of $24.03 \pm 2.67,9.79 \pm 2.03,13.17 \pm 3.43$ and $8.86 \pm 1.99 \mu \mathrm{g} / \mathrm{g}$ dry weight successively. The $\mathrm{Cd}$ was accumulated in liver, kidney, spleen, and gills of $S$. aurita in concentrations of $0.07 \pm 0.04,0.27 \pm 0.16,0.05 \pm .03$ and $0.02 \pm 0.006 \mu \mathrm{g} / \mathrm{g}$ dry weight successively. The $\mathrm{Pb}$ was accumulated in liver, kidney, spleen, and gills of $S$. aurita in concentrations of $1.00 \pm 0.12,15.30 \pm 1.70,13.36 \pm 7.28$ and $0.300 \pm 0.20 \mu \mathrm{g} / \mathrm{g}$ dry weight successively. At last, The $\mathrm{Hg}$ was accumulated in liver, kidney, spleen, and gills of $S$. aurita in concentrations of $0.134 \pm 0.030,0.141 \pm 0.024,0.111 \pm 0.027$ and $0.102 \pm$ $0.013 \mu \mathrm{g} / \mathrm{g}$ dry weight respectively (Table 4) and (Fig. 1).

\subsection{Histopathological findings}

Histopathological examination of the Atlantic horse Mackerel hepatopancreatic tissue have revealed the presence of marked coagulative necrosis of hepatic parenchyma while examination of Round sardinella hepatopancreatic tissue has revealed the presence of vaccuolar degeneration of hepatic parenchyma, perivascular fibrosis, and congestion of central vain. However, Common panadora hepatopancreatic tissue was presenting mild case of vaccuolar degeneration (Fig. 2). Atlantic horse Mackerel kidney tissue showed marked interstitial nephritis and hyalinosis in the wall of renal tubules while Round sardinella kidney tissue exhibited moderate tubular degeneration and interstitial lymphocytic infiltration. Yet, Common panadora exihibited mild tubular degeneration and interstitial lymphocytic infiltration (Fig. 2). The Atlantic horse Mackerel splenic tissue exhibited marked melanomacrographe centers activation while Round sardinella splenic tissue exhibited marked congestion of splenic blood vessels associated with severe lymphocytic infiltration. At last, Common panadora splenic tissue presented moderate congestion of splenic blood vessels associated with mild lymphocytic infiltration (Fig. 2). The Atlantic horse Mackerel gill tissue showed severe congestion of lamellar blood capillaries (Fig. 2) while Round sardinella gill tissue showed moderate lamellar necrosis (Fig. 2). The Atlantic horse Mackerel musculature revealed the presence of perivascular edema and hemorrhage in muscular tissue (Fig. 2). 


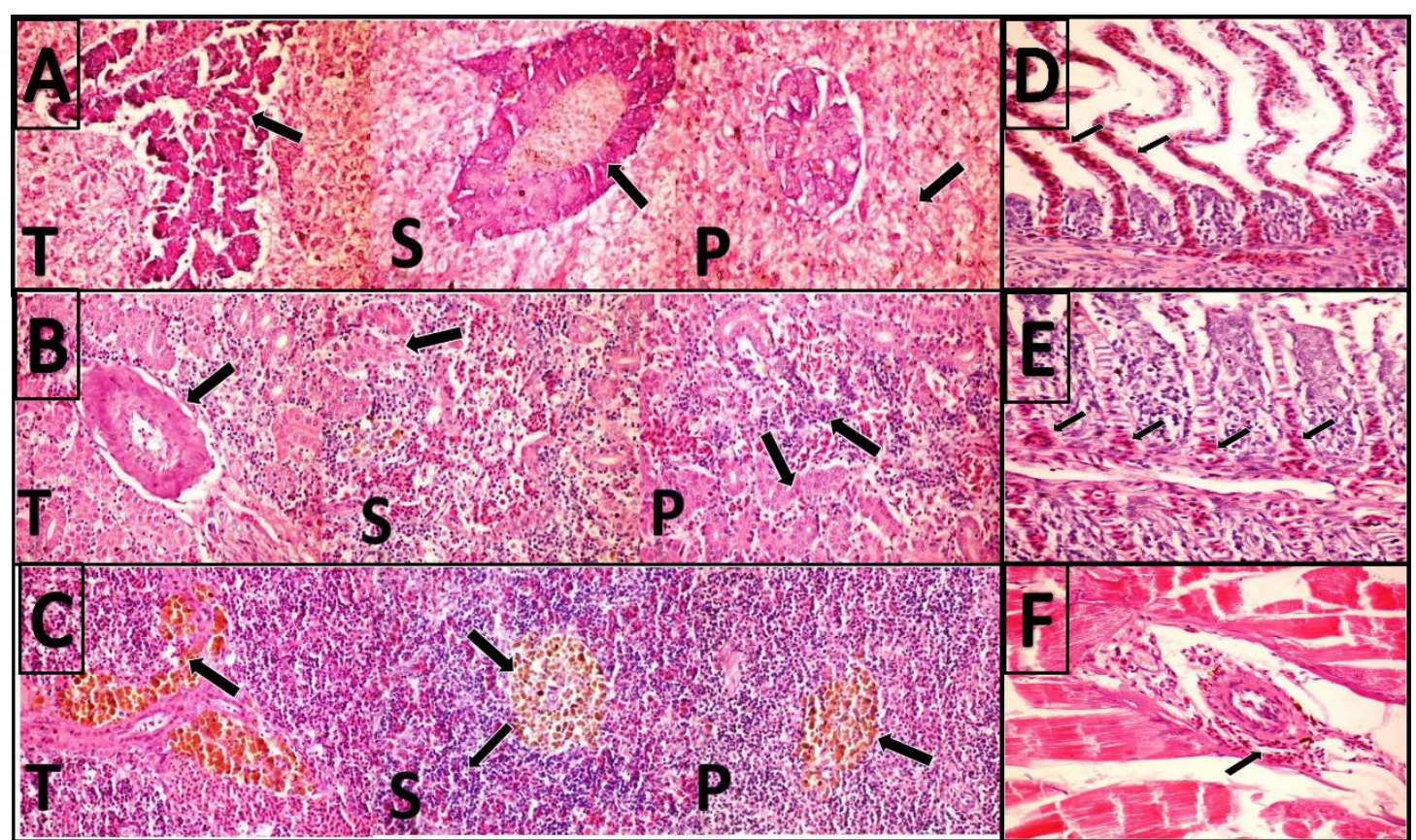

Fig. 2. A: T. Photomicrographs of the Atlantic horse Mackerel hepatopancreatic tissue with marked coagulative necrosis of hepatic parenchyma. S. Round sardinella hepatopancreatic tissue with vacuolar degeneration of hepatic parenchyma and perivascular fibrosis and congestion of central vain. P. Common panadora hepatopancreatic tissue with mild vacuolar degeneration. B: T. Photomicrographs of the Atlantic horse Mackerel kidney tissue showed marked interstitial nephritis and hyalinosis in the wall of renal tubules. S. Round sardinella kidney tissue with moderate tubular degeneration and interstitial lymphocytic infiltration. P. Common panadora with mild tubular degeneration and interstitial lymphocytic infiltration. C: T. Photomicrographs of the Atlantic horse Mackerel splenic tissue with marked melanomacrographe centers activation. S. Round sardinella splenic tissue with marked congestion of splenic blood vessels associated with severe lymphocytic infiltration. P. Common panadora splenic tissue with moderate congestion of splenic blood vessels associated with mild lymphocytic infiltration. D: Photomicrographs of the Atlantic horse Mackerel gill tissue showing severe congestion of lamellar blood capillaries. E: Photomicrographs of the Round sardinella gill tissue showing moderate lamellar necrosis. F: Photomicrograph of the Atlantic horse Mackerel with perivascular edema and hemorrhage in muscular tissue. All tissues stained with hematoxylin and eosin (x400).

\section{DISCUSSION}

Aquatic pollution of water bodies (e.g., seas, lakes, rivers, oceans, aquifers) with certain environmental pollutant is considered a major jeopardy among the top list of environmental pollutants directly impacting aquatic creatures (Ghannam, 2021). Among these direct impacts, they can produce mortality, endocrine disruption, reproductive failure, skeletal deformities (Eissa et al., 2009) and immunodeficiency (Eissa $\boldsymbol{e t}$ al., 2013). Also, it represents a dangerous risk on humans consumed sea food and other fish 
products contaminated by toxic elements for this reason, fish muscle is commonly analyzed to determine contaminants concentrations.

In the current study there several facts that have been assured from the results. It was noticeable that lengths pattern was $T$. trachurus $>S$. aurita $>P$. erythrinus while weights pattern was $T$. trachurus $>P$. erythrinus $>S$. aurita. This concords with the well-known fact that $T$. trachurus is long living fish followed by $\mathrm{S}$. aurita followed by $P$. erythrinus where fish length is directly proportional to fish age (Vrgoč, 2000). Further, it is expected that the longer the age the more accumulation of heavy metals in the tissues of the long-lived fish (Canli and Atli, 2003). Bioaccumulation of heavy metals is a gradual cumulative process where heavy metal concentrations gradually increase by increase of age because of the extension of the feeding periods than short, aged fish allowing them to accumulate much more metals than them (Canli and Atli, 2003). Moreover, the longer stay of fish in a polluted water allow them to uptake much higher metals through gills and skin than those with shorter ages (Ginsberg and Toal, 2009).

These assumptions are highly supported by results obtained in the current study as illustrated in table (3). These means of heavy metal concentration in muscles of the three examined fish is exclusively confirming that the accumulation pattern for the 5 tested heavy metals was $T$. trachurus $>S$. aurita $>$ P. erythrinus which is in strong accordance with the above-mentioned facts. The constant swimming patterns of T. trachurus and its usual existence closer to the sea floor with sometimes pectoral fin movement in place could explain why they tend to accumulate more heavy metals than do other mid-zone, surface feeding and pelagic fish. Their closer existence to the vicinity of the sea floor where most of heavy metals settle down by their molecular weight / gravity could explain why do $T$. trachurus muscles / organs do accumulate more heavy metals than do other $P$. erythrinus which is nearly mid-zone pelagic fish (Herrmann and Enders, 2000).

The statistical analysis of data achieved in the current study confirmed that muscles has possessed the lowest concentrations of heavy metals. It is generally accepted that heavy metals have low tendency to accumulate in muscles, where metabolic activity is relatively low (Kalay et al., 1999). Similar results were obtained showing that fish muscles are not biologically active organs in accumulating heavy metals (Ibrahim et al., 2000; Karaded et al., 2004; Hammoud et al., 2005; Yilmaz 2005; Bahnasawy et al., 2009; Bahnasawy et al., 2010). Meanwhile fish muscles have tendency to regulate heavy metals but, it can record high concentration when it is exposed to high polluted water (Du Preez et al., 1993).

The maximal levels of $\mathrm{Cu}$ allowed in fish muscles according to WHO (1990, 1993) is $20 \mathrm{mg} / \mathrm{g}$ muscle tissue then it was obvious that copper levels in the three tested fish in the current study were higher than permissible limits (Table 3). This could be supported by levels of $\mathrm{Cu}$ in seawater samples (1.0466) which exceeded maximal allowed limits (1 mg /L) as reported by WHO (1993) and USEPA (2001) (Table 2). The maximal 
levels of $\mathrm{Zn}$ allowed in fish muscles according to WHO (1993) is $100 \mathrm{mg} / \mathrm{g}$ muscle tissue. Then, it was obvious that $\mathrm{Zn}$ levels in the three tested fish in the current study were much lower than permissible limits (Table 3). This could be supported by levels of $\mathrm{Zn}$ in seawater samples $(0.228)$ which was much below maximal allowed limits $(5 \mathrm{mg} /$ L) reported by WHO (1993) and USEPA (2001) (Table 2). The maximal levels of Pb allowed in fish muscles according to WHO (1993) is $2.0 \mathrm{mg} / \mathrm{g}$ muscle tissue then it was obvious that $\mathrm{Pb}$ levels in the three tested fish in the current study were much lower than permissible limits (Table 3). This could be supported by levels of $\mathrm{Pb}$ in seawater samples (0.038) which was much below maximal allowed limits $(0.050 \mathrm{mg} / \mathrm{L})$ as reported by WHO (1993) and USEPA (2001) (Table 2). The maximal levels of $\mathrm{Cd}$ allowed in fish muscles according to WHO $(\mathbf{1 9 9 0}, \mathbf{1 9 9 3})$ is $0.5 \mathrm{mg} / \mathrm{g}$ muscle tissue then it was obvious that $\mathrm{Cd}$ levels in the three tested fish in the current study were much lower than permissible limits (Table 3). This could be supported by levels of Cd in seawater samples (0.038) which was much below maximal allowed limits $(0.050 \mathrm{mg} / \mathrm{L})$ as reported by WHO (1993) and USEPA (2001) (Table 2). The maximal levels of Hg allowed in fish muscles according to WHO $(\mathbf{1 9 9 0}, \mathbf{1 9 9 3})$ is $0.5 \mathrm{mg} / \mathrm{g}$ muscle tissue then it was obvious that $\mathrm{Hg}$ levels in the three tested fish in the current study were much lower than permissible limits (Table 3). This could be supported by levels of $\mathrm{Hg}$ in seawater samples $(0.029)$ which was much below maximal allowed limits $(0.050 \mathrm{mg} / \mathrm{L})$ as reported by WHO (1993) and USEPA (2001) (Table 2).

In the present study, different heavy metal levels were observed between the investigated fish species. T. trachurus accumulated the highest levels of the 5 tested heavy metals concentrations followed by $S$. aurita than P. erythrinus which presented the lowest concentration. Previous studies indicated that different concentrations of heavy metals in tissues of different fish species may be related to difference in ecological needs, metabolism, feeding habits, age, size, and their living habitats (Kijakovic et al., 2002; Canli and Atli, 2003 Karadede et al., 2004 and Bahnaswy et al., 2009). P. erythrinus is essentially carnivorous and feeds on small fish, crustaceans, worms, and other marine invertebrates (Relini $\boldsymbol{e t}$ al., 1999) who live deeper in the cleanest water zone of approximately $300 \mathrm{~m}$ depth and have pelagic seasonal inclination for spawning. S. aurita is a pelagic fish preferring clear saline shallow water, feeding mainly on Zooplankton and sometimes phyoplanktons while $T$. trachurus prefers feeding close to the sea floor where its favorite food (Crustaceans, molluscs, worms, decapods, isopods) exist. It is well documented that benthic fish such as $T$. tarchurus possess higher heavy metals concentrations in their tissues than pelagic fish (S. aurita and P. erythrinus), confirming the significant process of sedimentation and persistence of these metals in sea depths (Storelli et al., 2005). Filter feeding creatures such as crustaceans, molluscs, worms and water insects are known to have strong ability to store large quantities of heavy metals in their hemolymph and body tissues irrespective of their concentrations in water or 
sediment (Ibrahim et al., 1999a, 1999b, 2000; Ansari et al., 2004; Bahnasawy and ElBakkoch, 2009; Al-Arkat, 2010).

In the present study, the mean concentrations of both essential and non-essential metals in the liver, kidney, spleen, gills, and muscles of each fish species showed great variations. Also, statistical analysis revealed that metal concentrations were significantly different in each tissue from different fish species. The differences in the levels of accumulation in the different organs as tissues of a fish can primarily be related to the differences in the physiological role of each organ. Regulatory ability, behavior and feeding habits are other factors that could influence the accumulation differences in the different organs (Kotze et al., 1999).

It was also reported that the differences in tissues heavy metals concentrations may be attributed to their ability to induce metal-binding proteins such as metallothionein (Canli and Atli, 2003; Uysal, et al., 2008). The extracted results from the present study showed that $\mathrm{Cu}, \mathrm{Pb}, \mathrm{Cd}$ concentrations in the liver were highest in all fish studied while muscles appeared to be the least preferred site for the bioaccumulation of metals as the lowest metal concentrations were detected in these muscles. Studies carried out with various fish species have shown that heavy metals accumulate mainly in highly metabolic organs such as liver which detoxify stored metals by producing protein metallothionein (Ibrahim et al., 1999a, 1999b). In support to this, Benson et al., (2007) stated that liver is an organ where the specific metabolic and enzyme-catalyzed processes related to each heavy metals took place.

Statistical analysis of the results achieved in the current study indicated that heavy metal concentrations in different organs of T. trachurus, $S$. aurita and P. erythrinus have no specific patterns when comparing the residues of each metal in each organ of each individual fish species or combined. In respect to $T$. trachurus the heavy metals concentration pattern for zinc was Spleen $>$ Kidney $>$ Liver $>$ Gills. For $\mathrm{Cu}$ the pattern was Liver $>$ Spleen $>$ Kidney $>$ Gills. For Cd the pattern was Spleen $>$ Kidney $>$ Liver $>$ Gills. In case of $\mathrm{Pb}$ the pattern was like that of zinc i.e., Spleen $>$ Kidney $>$ Liver $>$ Gills. Finally, for $\mathrm{Hg}$ the pattern little bit different Liver > Kidney > Spleen> Gills (Table 4). These patterns revealed that gills exhibited the lowest accumulation patterns for all tested heavy metals while highest accumulation patterns alternated between liver in case of copper / mercury and spleen in case of zinc, cadmium, and lead. Kidney came second in order of levels of accumulation after spleen and liver. In case of $S$. aurita the heavy metals concentration pattern for zinc was Kidney $>$ Spleen $>$ Liver $>$ Gills. For copper the pattern was Kidney $>$ Spleen $>$ Liver $>$ Gills. For cadmium the pattern was Kidney > Liver $>$ Spleen $>$ Gills. In case of lead the pattern was like that of cadmium i.e., Kidney $>$ Liver $>$ Spleen $>$ Gills. Finally, for mercury the pattern was like that of zinc Kidney > Spleen $>$ Liver $>$ Gills (Table 4).

These patterns revealed that gills exhibited the lowest accumulation patterns for all tested heavy metals while highest accumulation patterns were presented by kidney 
followed by spleen then liver. For P. erythrinus the heavy metals concentration pattern for zinc was Kidney $>$ Spleen $>$ Liver $>$ Gills. For copper the pattern was Kidney $>$ Spleen $>$ Liver $>$ Gills. For cadmium the pattern was Kidney $>$ Liver $>$ Spleen $>$ Gills. In case of lead the pattern was like that of cadmium i.e., Kidney $>$ Liver $>$ Spleen $>$ Gills. Finally, for mercury the pattern was Kidney $>$ Liver $>$ Spleen $>$ Gills (Table 4). These patterns revealed that gills exhibited the lowest accumulation patterns for all tested heavy metals while highest accumulation patterns were presented by kidney followed by liver then spleen. The lowest accumulation patterns in gills of the three examined marine fish could be attributed to the unique cellular structure of branchial tissues in case of marine fish. Gills of marine fish are adapted to possess more powerful excretory / osmoregulatory function than do skin and kidneys of marine fish (Anni et al., 2016; Eissa, 2016). Thus, gills can get rid of larger amounts of heavy metals / salts using specific binding protein structures like lactins and powerful capability of the very welldeveloped chloride cells to pump out them into the water. Further, the potential cycle of gas exchange through the efferent / afferent branchial circulation is associated with release of water carrying fish waster products including gaseous and relatively fair number of solid wastes including mucus bind metals directly to the water stream (Eissa, 2016; Han et al., 2021). Moreover, the migratory behavior of these fish provides them with a gifted process of skin epitehlia/ gill epitehlia shedding before migration to another area of the sea based on salinity degree which might help them get rid of a large portion of the deposited heavy metals in their epithelia (Anni et al., 2016).

Finally, the highly dynamic function of gills and mechanical sieving function of gill rakers might have played a role in minimizing levels of metals in gills (Eissa, 2016). Our data coincide with those reported by Badr et al., (2014). However, our data are fairly in contradiction with those reported by metals (Wong et al., 2001; Bahnasawy et al., 2009) which could be attributed to degree of pollution, type of water, species, feeding habits, swimming habits, migration patterns, season, methods of sampling, time before analysis. When comparing the bioaccumulation patterns of the heavy metals in gills of the three examined marine species, it was noticeable that $T$. trachurus gills accumulate more heavy metals than $S$. aurita where both were higher than that of $P$. erythrinus. These data were supported with the degree of tissue alterations of gills of the three species where microscopical examination of tissue-stained sections of the E. rythrinus gill tissue showed no remarkable alteration within gill lamellae while T. trachurus gill tissue showed severe congestion of lamellar blood capillaries and finally S. aurita gill tissue showed moderate lamellar necrosis. Gills of fish are good indicators to bad water quality due to its direct exposure to water pollutants. (Ahmed et al., 2019). Consequently, the damage occurred in gills is attributed to toxic heavy metals present in water (El-Bakary et al., 2011; Anni et al., 2016).

Difference in feeding habits/type of food of the examined three fish might favor the enhanced accumulation of certain heavy metal than other as well as favor one fish 
over another in the total accumulation of heavy metals in their organs (Brili, 1996). For example, benthic fish like $T$. trachurus will always have higher heavy metal accumulation rate / levels than pelagic fish like $P$. eryrhinus and $S$. aurita (Kargin, 1996). Some heavy metals might have selective affinity to certain body organs. i.e., $\mathrm{Hg}$ has higher affinity to kidney (Bernhoftm, 2011), brain (Guzzi and La Porta, 2008) and liver. $\mathrm{Pb}$ has higher affinity to spleen, blood forming tissues, liver. $\mathrm{Cd}$ has special affinity to liver and spleen (Waalkes, 2003). Zinc has selective affinity to gonads, brain, muscles, and liver (Choi and Koh, 1998). Cu has affinity to liver, spleen, blood, and kidney (Authman and Abbas, 2007). These facts support the obtained heavy metal concentrations in different organs of the three examined fish where heavy metal accumulation patterns highly concordant with the hypothesis of metals selective affinity to certain organs (Table 4). Interestingly, the lower levels of $\mathrm{Hg}$ in muscles and organs of the examined fish perfectly accords with the hypothesis that $\mathrm{Hg}$ bio-amplifies in the food chain with high trophic levels than in low level benthic fish. Several studies documented that $\mathrm{Hg}$ greatly bio-amplifies in predatory species (such as sharks, cod, and tuna) than herbivorous and lower carnivorous benthic species (Storelli et al., 2005). The achieved hsitopathological alterations in liver, kidney and spleen confirms our assumption that the most pathologicaly affected fish was the $T$. trachurus followed by $S$. aurita and the least affected species was P. erythrinas. These supports the recorded pattern of heavy metal accumulation described before. Microscopical examination of tissue-stained sections of the $T$. trachurus tissue have revealed the presence of marked coagulative necrosis of hepatic parenchyma while examination of $S$. aurita hepatopancreatic tissue has revealed the presence of vaccuolar degeneration of hepatic parenchyma, perivascular fibrosis and congestion of central vain. However, P. erythrinus hepatopancreatic tissue was presenting mild case of vaccuolar degeneration. Also, microscopical examination of tissue-stained sections of T. trachurus kidney tissue showed marked interstitial nephritis and hyalinosis in the wall of renal tubules while $S$. aurita kidney tissue exhibited moderate tubular degeneration and interstitial lymphocytic infiltration. Yet, P. erythrinus exhibited mild tubular degeneration and interstitial lymphocytic infiltration. Further, microscopical examination of tissue-stained sections of the Atlantic horse Mackerel splenic tissue exhibited marked melanomacrographe centers activation while Round sardinella splenic tissue exhibited marked congestion of splenic blood vessels associated with severe lymphocytic infiltration. At last, Common panadora splenic tissue presented moderate congestion of splenic blood vessels associated with mild lymphocytic infiltration. These three of degrees of pathological alterations in liver, kidney, and spleen concord with the accumulation patterns of the heavy metals in the three examined fish as $T$. trachurs $>S$. aurita $>$ P. erythrinus. Also, lesions obtained in liver and kidney indicates how severe was the effect of heavy metals like $\mathrm{Hg}, \mathrm{Pb}, \mathrm{Cu}$ and $\mathrm{Cd}$ though in low concentration below the permissible limits. The interstitial nephritis and tubular degeneration are characteristic for $\mathrm{Hg}$ toxicity. Further, lead, copper and cadmium toxicity are associated 
with degenerative and necrotic changes in spleen with melanomacrophage center activation (MMC) (Badr et al., 2014). These results agreed with several previous studies in the past two decades (Authman and Abbas, 2007; Reksten et al., 2021). In addition, the pathological liver steatosis was reported by Kranz and Peters (1985) as a case accompanied by additional features such as necrosis, lymphocyte infiltration, deposition of ceroids and aggregations of macrophages.

\section{CONCLUSION}

The fish from Egyptian northwestern coasts (Salloum Bay \& Marsa Matrouh) are relatively healthier than fish from other coasts on the Mediterranean either from European or Arabian side due to lower heavy metal levels in the fish flesh which were less than WHO permissible limits. Moreover, laboratory assessments indicated that Common panadora fish was the least fish to accumulate heavy metals followed by Round Sardienlla followed by Atlantic horse mackerel with highest accumulation pattern. Statistical analysis revealed the presence of relative variation in the accumulation patterns between different examined organs for each tested metal and for each tested fish species. Gills was the least organ to accumulate any of the tested 5 metals while Liver, spleen and kidney have alternatively adopted the highest accumulation organ for $\mathrm{Zn}, \mathrm{Cu}, \mathrm{Cd}, \mathrm{Pb}$ and Hg. The recorded histopathological alterations with liver, kidney, spleen, gills, and muscles have confirmed that Atlantic horse mackerel were the most affected fish species followed by Round sardinella then Common panadora which appeared to be the least affected fish species. The higher levels of metal accumulation together with tissue alteration exhibited by Atlantic horse mackerel could nominate it to be a good candidate for biological monitoring of $\mathrm{Hg}, \mathrm{Pb}$ and $\mathrm{Cd}$. Finally, the remarkable ability of histopathological procedures to detect the tissue alterations induced by heavy metals could suggest it as reliable monitoring technique for detecting the heavy metal impacts on Mediterranean fish.

\section{REFERENCES}

Ahmed, Y. H.; Bashir, D. W.; Abdel-moneam, D. A.; Azouz, R. A. and Galal, M. K. (2019). Histopathological, biochemical, and molecular studies on the toxic effect of used engine oil on the health status of Oreochromis niloticus. Acta Histochemica, 121: 563-574. https ://doi. org/10.1016/j.acthis.2019.04.005

Al-Arkat, M. (2010). Evaluation of heavy metals pollution in some cartilaginous fish and marine invertebrates at Jamahiriya Coast of Zelitan. M. Sc. Thesis, Faculty of Art and Science, El-Merghib University, Libya.

Anni, I. S. A.; Bianchini, A.; Barcarolli, I. F.; Varela, A. S.; Robaldo, R. B.; Tesser, M. B. and Sampaio, L. A. (2016). Salinity influence on growth, osmoregulation, 
and energy turnover in juvenile pompano Trachinotus marginatus Cuvier 1832. Aquaculture, 455: 63-72.

Ansari, T.; Marr, I. and Tariq, N. (2004). Heavy metals in marine pollution perspective. A mini review. J. Appl. Sci., 4 (1): 1-20.

APHA (American Public Health Association), (2005). American Water Works Association: Standard methods for the examination of water and wastewater. New York.

Authman, M. and Abbas, H. H. (2007). Accumulation and distribution of copper and zinc in both water and some vital tissues of two fish species (Tilapia zilii and Mugil cephalus) of Lake Qarun. Fayoum province, Egypt. Pakistan Journal of Biological Science, 10(13): 2106-2122.

Badr, A. M.; Mahana, N. A. and Eissa, A. (2014). Assessment of heavy metal levels in water and their toxicity in some tissues of Nile tilapia (Oreochromis niloticus) in river Nile basin at greater Cairo, Egypt. Global Veterinaria, 13(4): 432-443.

Bahnasawy, M.; Khidr, A. and Dheina, N. (2010). Assessment of heavy metal concentrations in water, plankton, and fish of Lake Manzala, Egypt. Turk. J. Zool., 34: 1-10.

Benson, N.; Essien, J.; Williams, A. and Bassey, D. (2007). Mercury accumulation in fish from Tropical aquatic ecosystem in the Niger Delta, Nigeria. Current Science, 92 (6): 781-785.

Bernhoft, R. A. (2011). Mercury toxicity and treatment: a review of the Lature. Journal of environmental and public health, 2012.

Brili, R. (1996). Selective advantages conferred by the high-Performance physiology of tunas, billfish and dolphin fish. Comp. Biochem. Physiol., 113: 3-15

Canli, M. and Atli, G. (2003). The relationships between heavy (Cd, Cr, Cu, Fe, Pd, Zn) levels and the size of six Mediterranean fish species. Environmental pollution, 121 (1): 129-136.

Choi, D. W. and Koh, J. Y. (1998). Zinc and brain injury. Annual review of neuroscience, 21(1): 347-375.

Du Preez, H.; Van Rensburg, E. and Van Vuren, J. (1993). Preliminary Laboratory investigation of the bioaccumulation of $\mathrm{Zn}$ and $\mathrm{Fe}$ in selected tissues of the Banded Tilapia, tilapia sparmanii (Chichlidae). Bull. Environ. Contam.Toxicol., 50: 67-681. 
Eissa, A. E. (2016). Clinical and Laboratory Manual of Fish Diseases. Lap Lambert Academic Publishing, ISBN: 3659876127. P.140.

Eissa, A. E.; Moustafa, M.; El-Husseiny, I. N.; Saeid, S.; Saleh, O. and Borhan, T. (2009). Identification of some skeletal deformities in freshwater teleosts raised in Egyptian aquaculture. Chemosphere, 77(3): 419-425.

Eissa, A. E.; Tharwat, N. A. and Zaki, M. M. (2013). Field assessment of the midwinter mass kills of trophic fish at Mariotteya stream, Egypt: Chemical and biological pollution synergistic model. Chemosphere, 90(3): 1061-1068.

El-Bakary, N. E. R.; Said, S. B. and El-Badaly, A. (2011). Using Oreochromis niloticus for assessment of water quality in water treatment plants. World Applied Sciences Journal, 12(9): 1455-1463.

El-Bakkoch, F. (2009). Assessment of some heavy metal's pollution in some marine fish at El-Khoms region, Great Gamahiriya. M. Sc. Thesis, Faculty of Science ElMerghib University, Libya.

Erdoğrul, Ö. and Erbilir, F. (2007). Heavy metal and trace elements in various fish samples from Sir Dam Lake, Kahramanmaraş, Turkey. Environmental Monitoring and Assessment, 130(1-3): 373-379.

Ghannam, H.E. (2021). Risk assessment of pollution with heavy metals in water and fish from River Nile, Egypt. Applied Water Science, 11:125. https://doi.org/10.1007/s13201-021-01449-7

Ginsberg, G.L. and Toal, B.F. (2009). Quantitative approach for incorporating methylmercury risks and omega-3 fatty acid benefits in developing speciesspecific fish consumption advice. Environ Health Perspect, 117: 267-275.

Guzzi, G. and La Porta, C. A. (2008). Molecular mechanisms triggered by mercury. Toxicology, 244(1): 1-12.

Hammoud, V.; Akdah, M. and Saad, A. (2005). Heavy metals Concentration in different tissues of fish, Diplodus sargus, in the Syrian Coast. J. Basel Al-Asad Eng. Sci., 21: 27-45.

Han, J.; Pan, X.; Qing Chen, Q. and Bai- Fen Huang, B. (2021). Health risk assessment of heavy metals in marine fish to the population in Zhejiang, China, Scientific Reports,11:11079. https://doi.org/10.1038/s41598-021-90665-x

Herrmann, J.P. and Enders, E.C. (2000). Effect of body size on the standard metabolism of horse mackerel. J. Fish Biol. 57: 746-760. 
Hseu, Z.Y. (2004). Evaluating heavy metal contents in nine composts using four digestion methods. Bioresourse Technology, 95: 53-59.

Ibrahim, A.; Bahnasawy, M.; Mansy, S. and El-Fayomy, R. (1999a). Heavy metal accumulation in water, Sediment and some fish in Lake Manzala, Egypt. J. Egypt. Ger. Soc. Zool., 29 (B): 43-58.

Ibrahim, A.; Bahnasawy, M.; Mansy, S. and El-Fayomy, R. (1999b). Distribution of heavy metals in the Damietta Nile Estuary Ecosystem. Egypt. J. Aquat. Biol and Fish., 3(4): 369-397.

Ibrahim, A.; Bahnasawy, M.; Mansy, S. and El-Fayomy, R. (2000). On some heavy metal levels in water, sediment, and marine Organisms from the Mediterranean Coast of Lake Manzala. Egypt. J. Aquat. Biol and Fish., 4 (4): 61-81.

Ismail, E.M.; Kadry, M.; Elshafiee, E.A.; Ragab, E.; Morsy, E.A.; Rizk, O. and Zaki, M.M. (2021). Ecoepidemiology and Potential Transmission of Vibrio cholerae among Different Environmental Niches: An Upcoming Threat in Egypt. Pathogens, 10: 190. https://doi.org/ 10.3390/pathogens10020190

Kalay, M.; Ay, Ö. and Canli, M. (1999). Heavy metal concentrations in fish tissues from the Northeast Mediterranean Sea. Bulletin of Environmental Contamination and Toxicology, 63(5): 673-681.

Karadede, H; Oymak, S. and Unlu, E. (2004). Heavy metals in mullet, Liza abu, and Catfish, Silurus triostegus, from the Ataturk Dam Lake (Euphrates), Turkey. Environment Internationl, 30: 183-188.

Kargin, F. (1996). Seasonal changes in levels of heavy metals in tissues Of Mullus barbatus and Sparus aurata collected from Iskenderun Gulf (Turkey). Water Air Soil Pollut., 90: 562.

Kotze, p.; Du preez, H. and Van Vuren, J. (1999). Bioaccumulation of Copper and Zinc in Oreochromis mossambicus and Clarias Gariepinus, from the Olifants River, Mpumalanga, South Africa. Water SA, 25 (1): 99-110.

Kranz, H. and Peters, N. (1985). Pathological conditions in the liver of ruffe, Gymnocephalus cernua (L.), from the Elbe estuary. Journal of Fish Diseases, 8(1): $13-24$

Mahjoub, M.; Fadlaoui, S.; El Maadoudi, M. and Youssef Smiri, Y. (2021). Mercury, Lead, and Cadmium in the Muscles of Five Fish Species from the Mechra aHammadi Dam in Morocco and Health Risks for Their Consumers. Hindawi Journal of Toxicology, ID. No. 8865869: 10 pages. https://doi.org/10.1155/2021/8865869 
Prophet, E. B.; Mills, B.; Arrington, J. B. and Sobin, L. H. (1992). Armed forces institute of pathology. Laboratory methods in histotechnology, 56: 151-164.

Rakib, R.J.; Jolly, Y. N.; Enyoh, C.E.; Khandaker, M.U.; Hossain, M.; Akther, S.; Alsubaie, A.; Almalki, A.S.A. and Bradley, D. A. (2021). Levels and health risk assessment of heavy metals in dried fish consumed in Bangladesh. Scientific Reports, 11:14642. https://doi.org/10.1038/s41598-021-93989-w

Reksten, A.M.; Rahman, Z.; Kjellevold, M.; Gamarro, E. G.; Thilsted, S.H.; Pincus, L.M.; Aakre, I.; Ryder, J.; Ariyawansa, S.; Nordhagen, A. and Lundebye, A. (2021). Metal Contents in Fish from the Bay of Bengal and Potential Consumer Exposure-The EAF-Nansen Programme. Foods 2021, 10, 1147. https://doi.org/10.3390/foods10051147

Storelli, M. M.; Giacominelli-Stuffler, R.; Storelli, A. and Marcotrigiano, G. O. (2005). Accumulation of mercury, cadmium, lead and arsenic in swordfish and bluefin tuna from the Mediterranean Sea: a comparative study. Marine pollution bulletin, 50 (9): 1004-1007.

Uysal, K.; Emre, Y. and Köse, E. (2008). The determination of heavy metal accumulation ratios in muscle, skin and gills of some migratory fish species by inductively coupled plasma-optical emission spectrometry (ICP-OES) in Beymelek Lagoon (Antalya/Turkey). Microchemical Journal, 90(1): 67-70.

Vrgoč, N. (2000) Struktura i dinamika pridnenih zajednica riba Jadranskog mora. Disertacija. Sveučilište u Zagrebu. 198 pp.

Waalkes, M. P. (2003). Cadmium carcinogenesis. Mutation Research/Fundamental and Molecular Mechanisms of Mutagenesis, 533(1): 107-120.

Wong, C.; Wong, P. and Chu, L. (2001). Heavy metal concentrations in marine fish collected from fish culture sites in Hong Kong. Arch. Environ. Contam .Toxicol ., 40: 60-69 .

Yilmaz, B. (2005). Comparison of Heavy metal levels of grey mullet (Mugil cephalus) and sea bream (Sparus aurata) caught in Iskenderun Bay (Turkey). Turk. J. Vet. Anim. Sci. 29: 257-262.

Yousif, R.A.; Choudhary, M.I.; Ahmed, S. and Ahmed, Q. (2021). Review: Bioaccumulation of heavy metals in fish and other aquatic organisms from Karachi Coast, Pakistan. Nusantara Bioscience, 13(1): 73-84. 